\title{
Improvement of Indoor Thermal Environment in Renovated Huizhou Architecture
}

\author{
Jie Zhong ${ }^{1,2^{*}}$, Shanghong Jia ${ }^{1,2}$, Renyi Liu ${ }^{1,2}$ \\ ${ }^{1}$ College of Architecture and Urban Planning, Anhui Jianzhu University, Hefei 230022, China \\ ${ }^{2}$ Key Laboratory of Huizhou Architecture in Anhui Province, Anhui Jianzhu University, Hefei 230022, China
}

Corresponding Author Email: jsh@ahjzu.edu.cn

https://doi.org/10.18280/ijht.370235

Received: 20 January 2019

Accepted: 1 April 2019

\section{Keywords:}

Huizhou architecture, renovation, wind environment, indoor ventilation

\begin{abstract}
Huizhou architecture can provide a relative comfortable indoor experience in summer, but failing to achieve the same effect in winter. This paper tested the thermal comfort in Xingfu Hall of Wufu Club, a renovated Huizhou architecture project, revealing that the hall was stiflingly hot in summer, due to slow wind speed and poor vetilation. Then, the indoor thermal environment of Wufu Club was simulated on the software PHOENICS. The simulation shows that the ventilation effect could be improved by increasing the size of wind outlet (the patio opening) and the absolute difference between the surface wind pressure at the new opening and the wind pressure of the existing openings.
\end{abstract}

\section{INTRODUCTION}

Huizhou architecture is one of the most important schools of traditional Chinese architecture. Many ancient buildings in the historical Huizhou Prefecture (now Huangshan Prefecture, Anhui Province, China) are well preserved. However, the indoor comfort of ancient buildings can no longer satisfy the living needs of modern people. The existing studies have shown that the thermal performance of Huizhou architecture can provide a relative comfortable indoor experience in summer, but failing to achieve the same effect in winter.

To improve the thermal comfort, many scholars and engineers have attempted to renovate Huizhou architecture. There is an abundance of renovation cases and rich research results. Nevertheless, the existing renovation methods emphasize too much on heat preservation in winter over the heat dissipation in summer. What is worse, most of the current renovations only focus on the spatial effect of the building rather than the passive energy-saving technique.

In this paper, the passive energy saving technique is highlighted in the renovation of Huizhou architecture. Based on the measured data of several renovated buildings, the ventilation performance of these buildings was simulated on the software PHOENICS, aiming to disclose how the indoor comfort is affected by the air inlet/outlet area without relying on active cooling. On this basis, several suggestions were presented for the renovation of Huizhou architecture. The research findings lay a scientific basis for improving the indoor comfort and promoting the sustainability of Huizhou architecture.

\section{OVERVIEW OF STUDY AREA}

Our study targets Wufu Club in Xiuning County, Huangshan Prefecture. The club has eight Ming and Qing dynasty buildings, all of which were relocated from other places in the county. The garden-like buildings cover a total area of $2,000 \mathrm{~m}^{2}$.
As a landmark of Wan'an Ancient Town, Wufu Club is bordered by the Hengjiang River on the south and embraced by mountains in the southwest and the north. In Chinese geomancy (Fengshui), this spatial pattern promises good fortune to the dwellers. The aerial view and master plan of the study area are shown in Figure 1 [1-3].

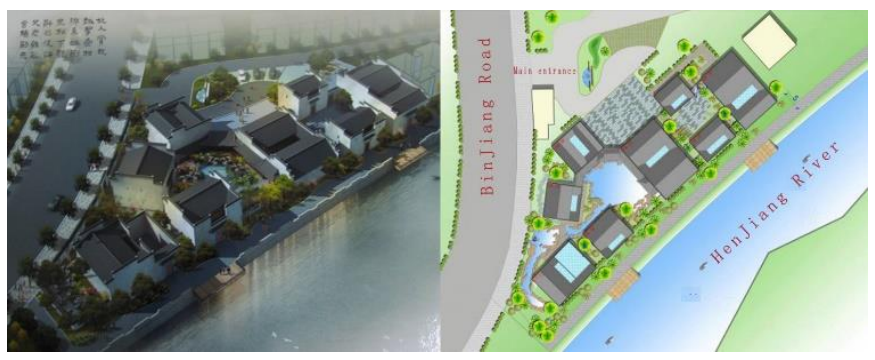

Figure 1. Aerial view and master plan of the study area

\section{RENOVATION MEASURES}

The renovation plan for Wufu Club was prepared scientifically in the light of the landform, architectural style and building quality. The typical elements of Huizhou architecture (e.g. small courtyards and narrow alleys) were fully integrated with the beautiful waterscape of the Hengjiang River, creating a leisure space that is clean, pleasant, comfortable and safe.

Considering the original functions and spatial features of the eight buildings, the designer rearranged the functional modules and adopted various technical measures, e.g. closing the patios, collecting rainwater, adding bathrooms, as well as designing energy-saving walls, doors, windows and roofs. In this way, the renovated buildings consume fewer energy after the renovation, easing the burden on the operator and the damage to the environment [4-7]. 


\section{TEST ON INDOOR THERMAL ENVIRONMENT OF RENOVATED BUILDINGS}

\subsection{Overview of the object}

The largest building of Wufu Club is called Xinfu Hall (Figure 2). The hall is a single-story building with a large patio (Figure 3). Multiple measures were adopted to renovate this building: (1)The external walls were rebuilt with concrete porous bricks and provided with an inner insulation system; (2) The patio was added with an openable glass louver, which can be opened in two directions using the electric sliding track; (3) The roof was protected by a waterproof insulation layer.

In our test, the indoor thermal environment of Xinfu Hall was measured in summer, and compared with that measured in an unrenovated Huizhou architecture. The comparison attempts to evaluate the effect of the renovation measures.

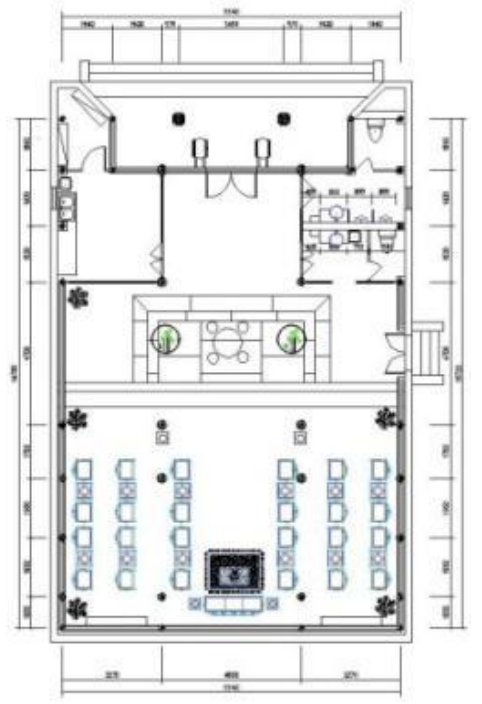

Figure 2. The floor plan of Xinfu Hall

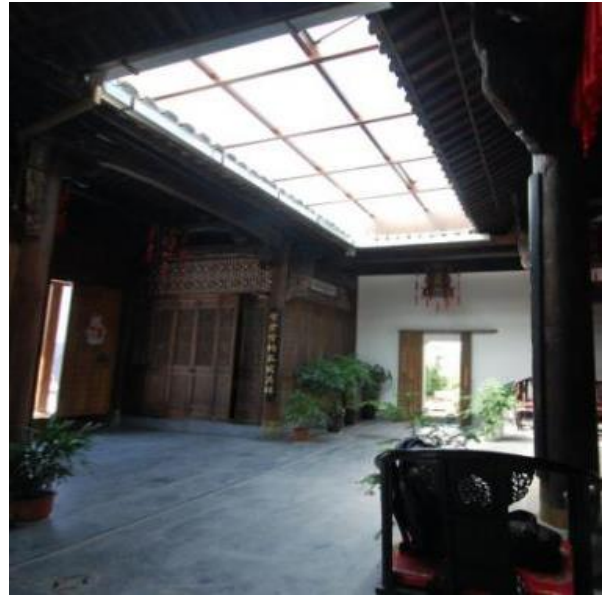

Figure 3. The renovated patio

\subsection{Results analysis}

The temperature and humidity measured inside and outside of Xinfu Hall are respectively plotted as Figures 4 and 5. It can be seen that the indoor temperature was much lower than the outdoor temperature, and increased with the latter. In addition, the indoor temperature of Xinfu Hall, which is a single-story building, was below that on the second floor of the contrastive architecture.

As shown in Figure 6, the air temperature and the predicted percentage dissatisfied (PPD) were respectively above $31{ }^{\circ} \mathrm{C}$ and $80 \%$ throughout the day, indicating that the indoor thermal environment is poor without air conditioning.

It can be seen from Figure 7 that the relative humidity inside the hall fluctuated between $47 \%$ and $68 \%$, with the change of temperature. This humidity range is relatively comfortable to occupants. As shown in Figure 8, the high wind speed was measured in several periods each day. The wind blew through the hall frequently from 9:00 to 19:00, and remained calm in other periods.

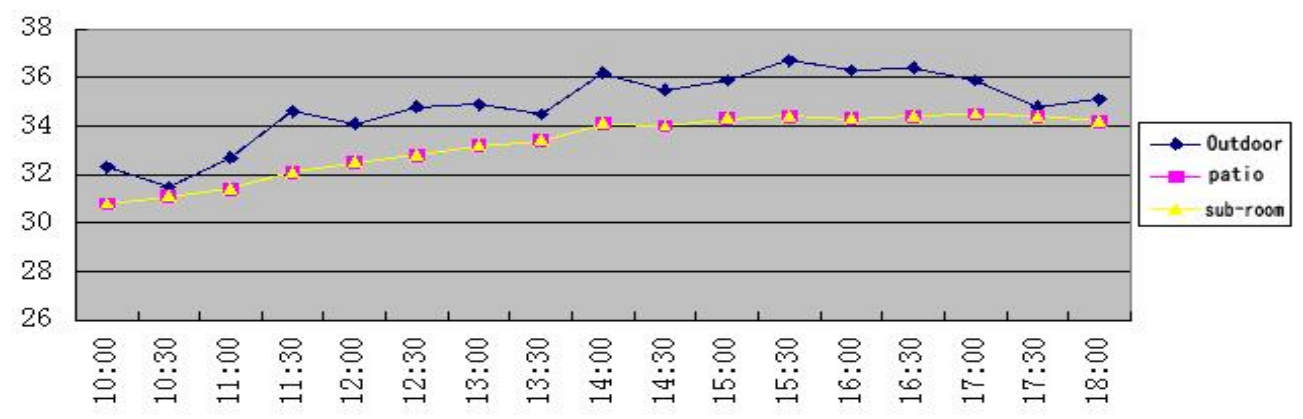

Figure 4. Indoor and outdoor temperatures

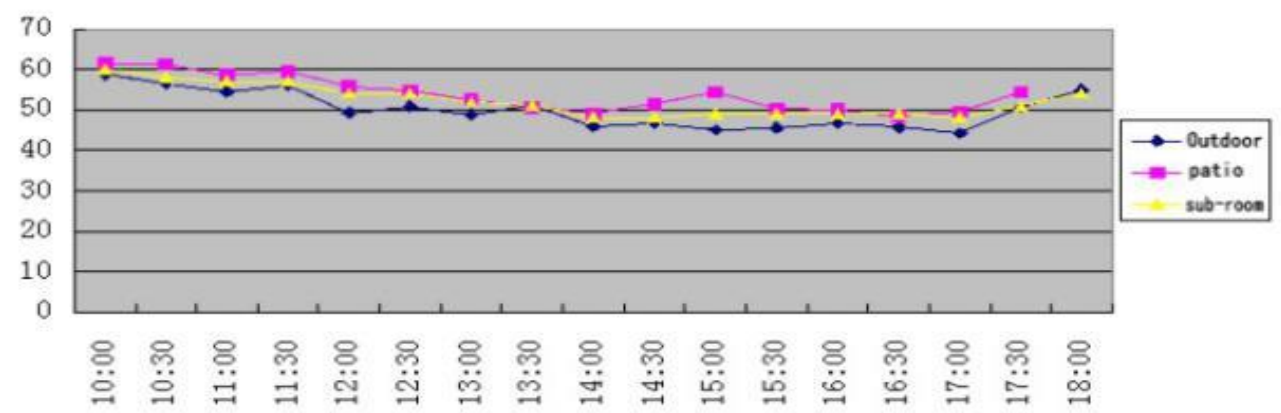

Figure 5. Indoor and outdoor humidity 


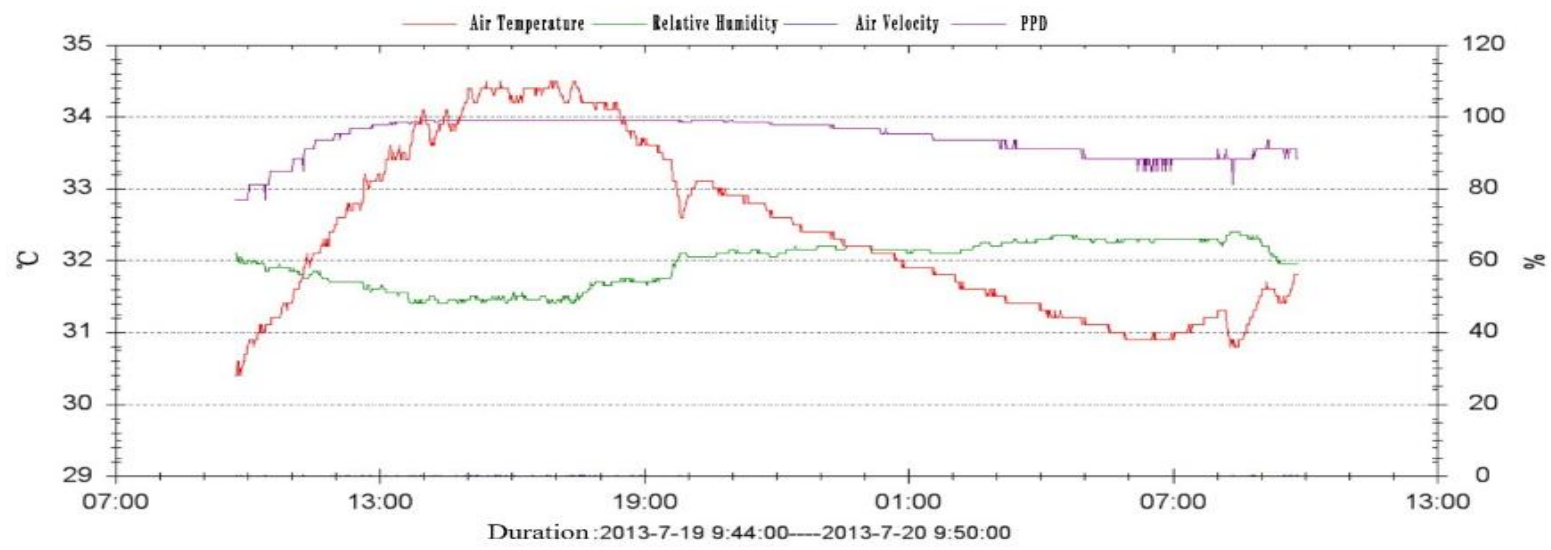

Figure 6. Relationship between air temperature, relative humidity, wind speed and the PPD

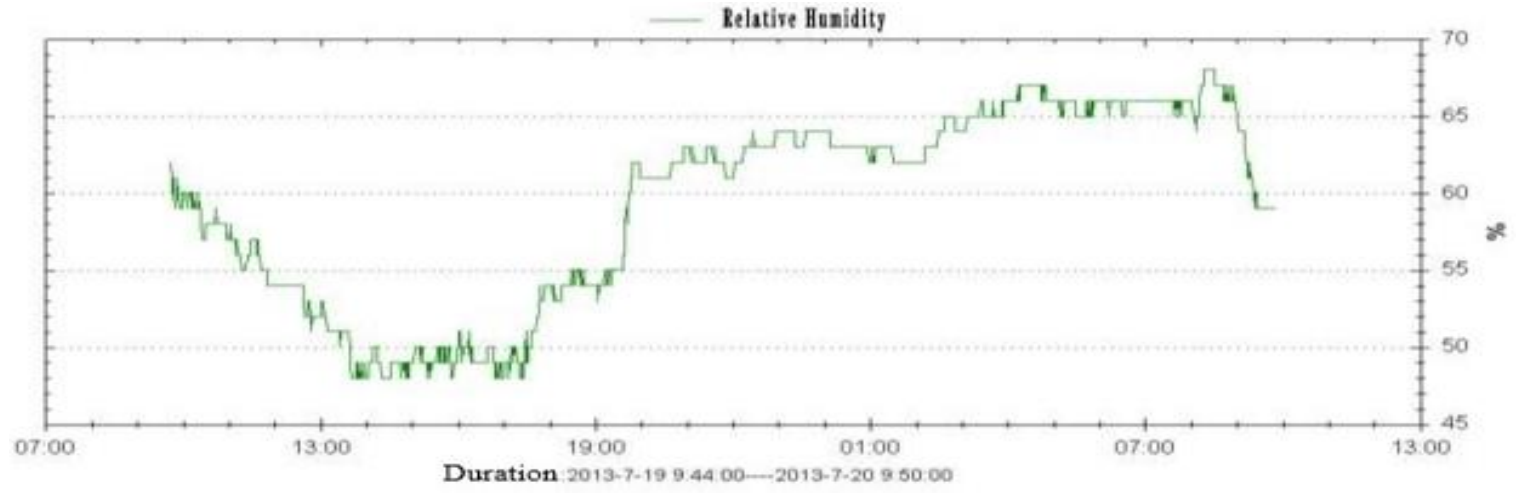

Figure 7. Time variation of relative humidity

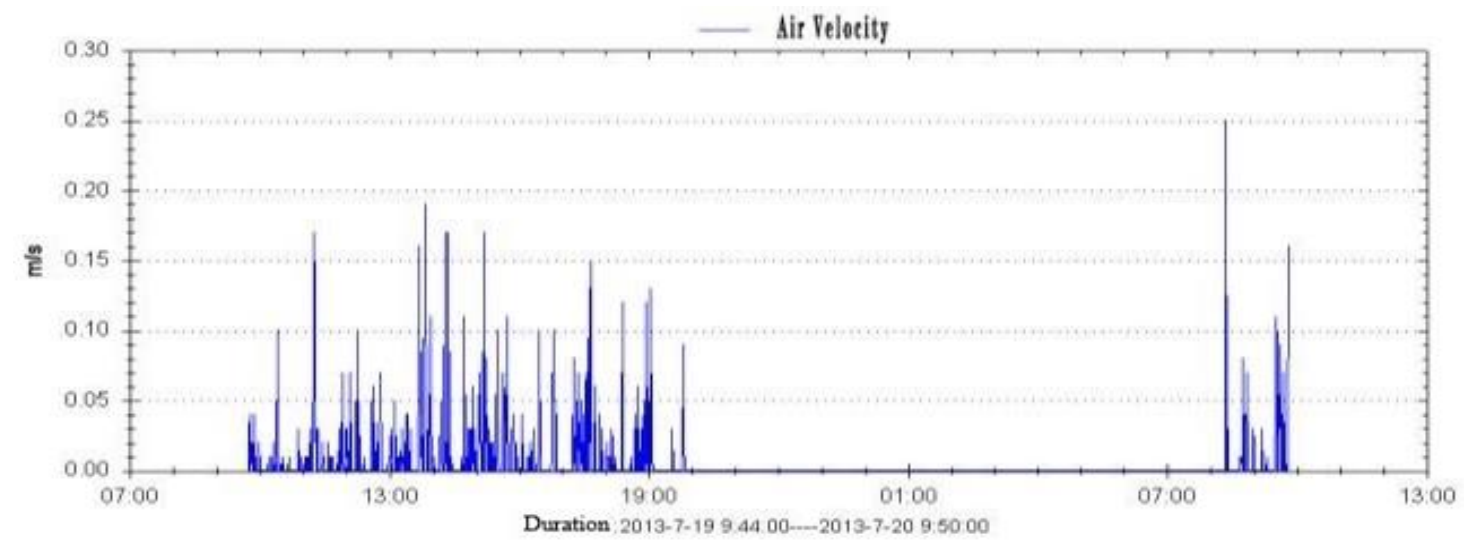

Figure 8. Time variation of wind speed

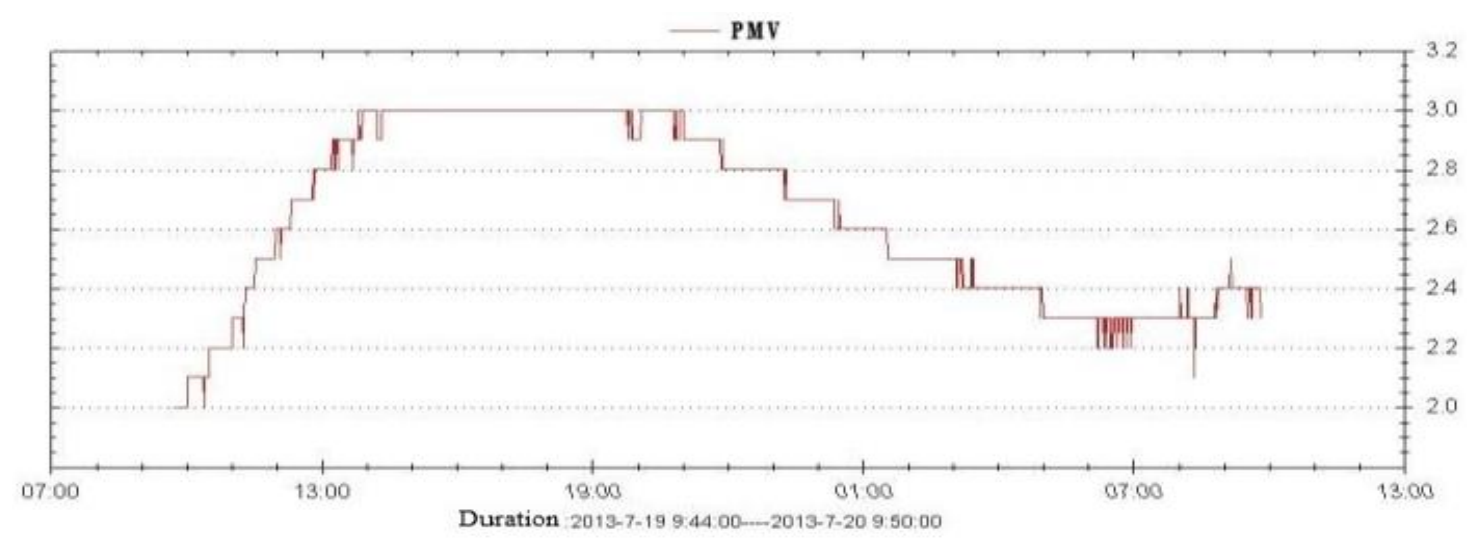

Figure 9. Time variation of the PMV 


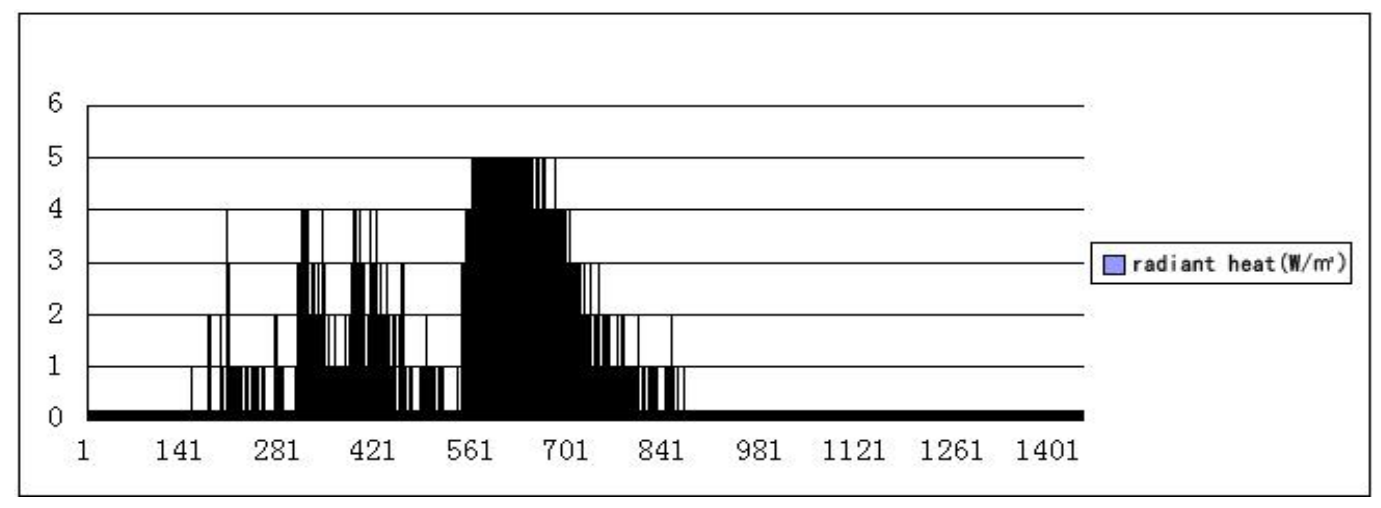

Figure 10. Time variation of radiant heat

It can be seen from Figure 9 that the predicted mean vote (PMV) inside the hall remained above 2 throughout the day, and peaked at 3 between 13:00 and 20:00. This means the indoor thermal environment is rather poor. Despite the thermal insulation measures adopted for renovation, Xinfu Hall fails to catch up with the contrastive architecture in indoor comfort during the summer.

Figure 10 demonstrates the good heat insulation effect of the roof of the hall. The radiant heat was controlled at low levels, even in the periods with the strongest sunlight. After dusk, the roof was relatively hot due to daytime solar radiation, and started to radiate heat into the room. The radiation process ended at around 00:00 [8].

The test on the renovated hall reveals different degrees of improvement to the sanitation and winter thermal environment. However, the hall was stiflingly hot in summer, due to slow wind speed and poor vetilation [9].

\section{SIMULATION ANALYSIS}

\subsection{Software settings}

The wind environment was simulated from the outdoor to the indoor. The outdoor wind environment was simulated first to obtain the wind pressure on the surface of the target building (the white building in Figure 1). Then, the indoor wind environment was simulated, according to the known wind pressure at each opening of the building.

The simulation of outdoor wind environment covers all the buildings which are four times as long as the target building. Let $\mathrm{H}$ be the length of the target building. Then, the computation area is $9 \mathrm{H}$ in length and $3 \mathrm{H}$ in height. The other parameters are listed in Table 1 [10].

Table 1. Parameters of outdoor wind environment simulation

\begin{tabular}{ccccccc}
\hline Item & Wind direction & Wind speed $(\mathrm{m} / \mathrm{s})$ & Profile type & Power law & Turbulence model & Total number of iterations \\
\hline Parameter value & Southwest & 1.4 & Power law & 0.143 & K-epsilon model & 2000 \\
\hline
\end{tabular}

For the simulation of indoor wind environment, the minimize grid size was set as half the dimension of the smallest part of the buildings. The wind pressure at each opening is given in Table 2 below.

Table 2. Wind pressure at each opening for indoor wind environment simulation

\begin{tabular}{cccccccc}
\hline Location & $\begin{array}{c}\text { Northwest } \\
\text { door }\end{array}$ & $\begin{array}{c}\text { Southwest } \\
\text { door }\end{array}$ & $\begin{array}{c}\text { Northeast } \\
\text { door }\end{array}$ & $\begin{array}{c}\text { Pati } \\
\text { o }\end{array}$ & $\begin{array}{c}\text { New southwest } \\
\text { window }\end{array}$ & $\begin{array}{c}\text { New northeast } \\
\text { window }\end{array}$ & $\begin{array}{c}\text { New southeast } \\
\text { window }\end{array}$ \\
\hline $\begin{array}{c}\text { Wind pressure } \\
(\mathrm{Pa})\end{array}$ & -0.15 & 0.15 & 0.15 & -0.1 & 0.3 & 0.2 & 0.05 \\
\hline
\end{tabular}

\subsection{Indoor and outdoor wind environments}

\subsubsection{Simulation results}

The following can be inferred from the simulated outdoor wind environment of the hall in summer (Figure 11). When the southwest wind blew at $1.4 \mathrm{~m} / \mathrm{s}$, the wind speed around the hall fell in the range of $0 \sim 0.5 \mathrm{~m} / \mathrm{s}$, peaking at $0.5 \mathrm{~m} / \mathrm{s}$, the surface wind pressure of the hall ranged between -0.3 and $0.4 \mathrm{~Pa}$, and the maximum and minimum wind pressures were observed on the northeast gable of the ancestral hall and the roof of the lobby (Figure 12).

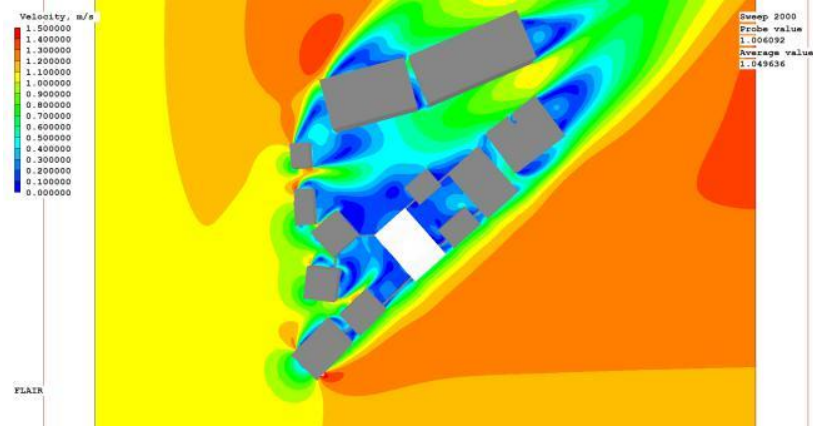

Figure 11. Outdoor wind speed 


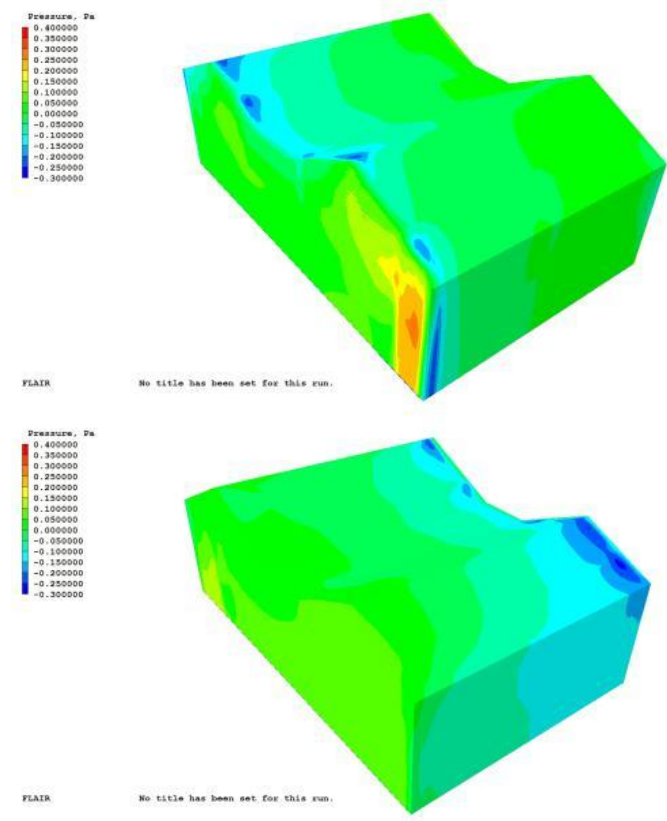

Figure 12. Surface wind pressure

The following can be observed when the patio of the hall was completely closed (Figure 13). When the wind outdoor blew in the typical direction at the typical speed in summer, the wind speed inside the hall fell within $0 \sim 0.05 \mathrm{~m} / \mathrm{s}$ at the height of $1.5 \mathrm{~m}$, that around each opening stood at $0.015 \sim 0.05$ $\mathrm{m} / \mathrm{s}$, and that in the other areas stayed below $0.015 \mathrm{~m} / \mathrm{s}$. The air age remained under $4,000 \mathrm{~s}$ at the height of $1.5 \mathrm{~m}$ indoor, except the area within $3 \mathrm{~m}$ off the southwest wall of the lobby.

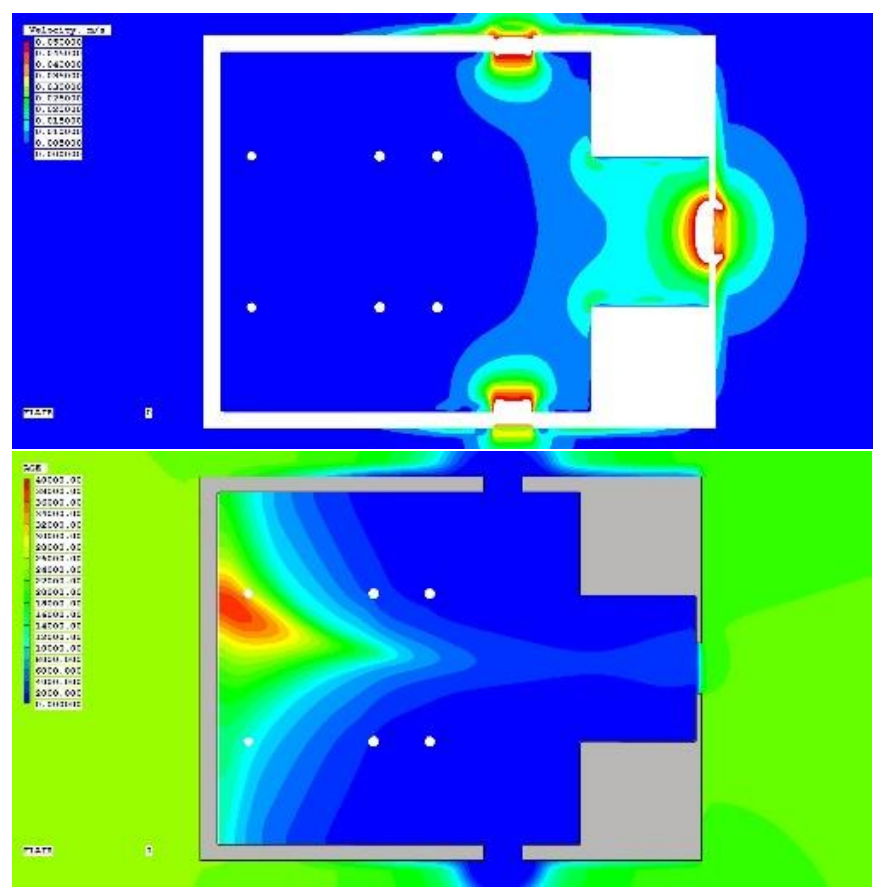

Figure 13. Wind speed and air age at the height of $1.5 \mathrm{~m}$

\subsubsection{Results analysis}

The above analysis shows that the wind speed around the hall was slow in summer, peaking at $0.5 \mathrm{~m} / \mathrm{s}$ only. This is attributable to two factors: (1) The outdoor buildings are arranged in rows, which are parallel to the typical wind direction in summer; this arrangement blocks the air flow into the main openings; (2) The buildings are densely built in the study area; the surrounding buildings and the enclosure severely impede the air flow into the target building.

In addition, the indoor ventilation of the hall was poor when the patio was closed. This is because of the slow wind speed entering the openings, as well as the small size and irrational layout of the openings [11].

\section{SIMULATION OF IMPROVEMENT PLANS FOR INDOOR WIND ENVIRONMENT}

The renovation of Huizhou architecture is constrained by the original structure and room functions. The improvement plan for indoor thermal environment should not endanger building stability or cause losses of room functions. The common way to improve indoor thermal environment in summer is to optimize the indoor ventilation.

To maintain the building stability and style, the indoor ventilation of the target building could be improved by enlarging the patio opening and adding more openings. The two improvement plans were compared through software simulation.

\subsection{Plan 1 (enlarging the patio opening)}

The patio of the target building has a partially openable cover. In view of the small opening, Plan 1 is to improve the indoor ventilation by enlarging the opening of the patio. Without changing the wind pressure at each opening, the indoor thermal environment was simulated at the patio opening of $5 \mathrm{~m}^{2}, 10 \mathrm{~m}^{2}$ and $15 \mathrm{~m}^{2}$, respectively. The simulation results are recorded in Figures 14 16.

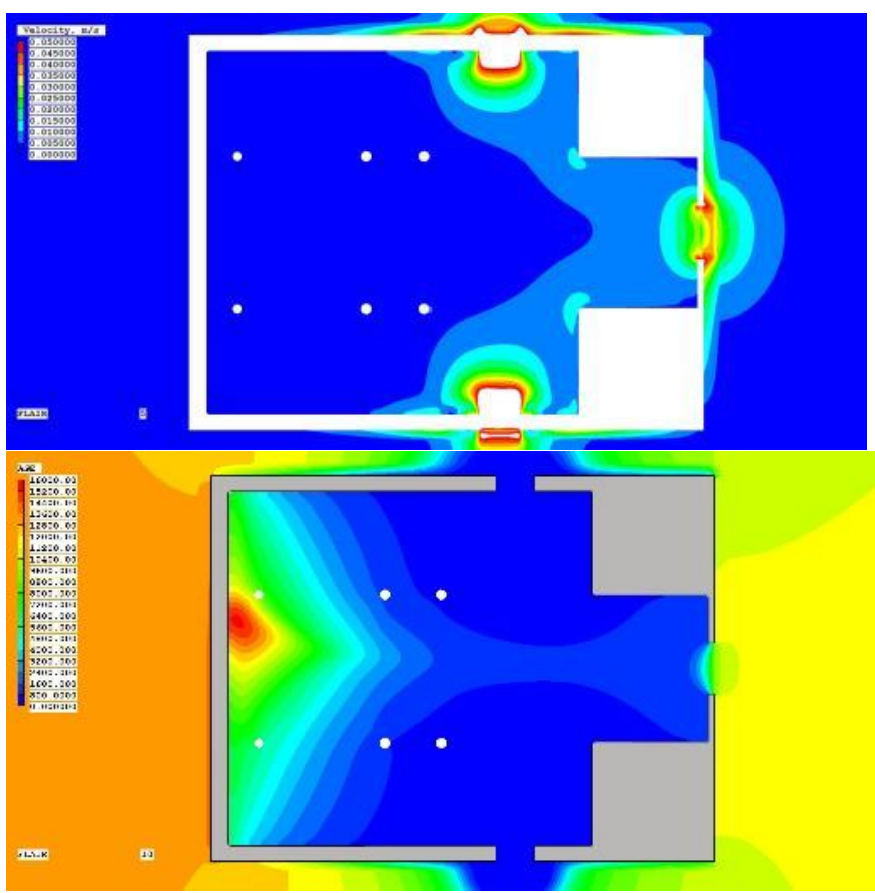

Figure 14. The wind speed and air age at the height of $1.5 \mathrm{~m}$ when the patio opening is $5 \mathrm{~m}^{2}$

The simulation results show that the indoor wind speed fell in $0 \sim 0.05 \mathrm{~m} / \mathrm{s}$, and the indoor air age peaked at $16,000 \mathrm{~s}$, $14,000 \mathrm{~s}$ and $13,500 \mathrm{~s}$ at the three patio openings, respectively. Hence, enlarging patio opening could not greatly improve the 
indoor thermal environment. Despite the increase in patio opening, the indoor wind speed remained unchanged, while the indoor air age was improved only slightly. A possible reason lies in the small absolute difference between the patio opening and other openings in wind pressure. The growth in patio opening cannot create a strong air draft.

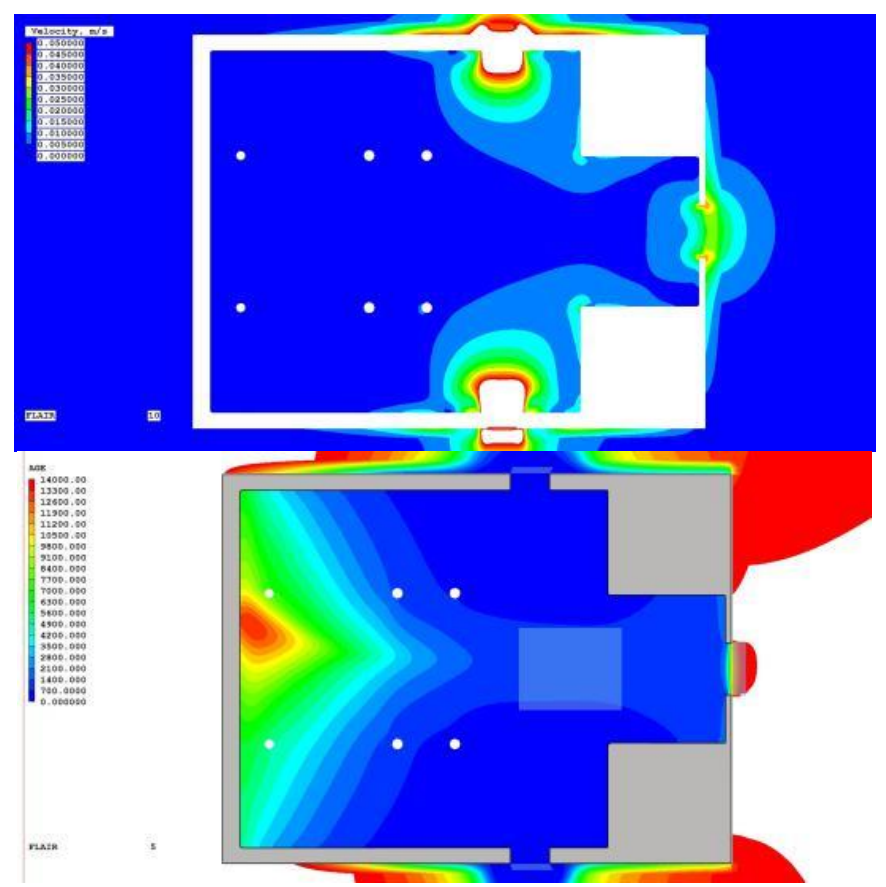

Figure 15. The wind speed and air age at the height of $1.5 \mathrm{~m}$ when the patio opening is $10 \mathrm{~m}^{2}$
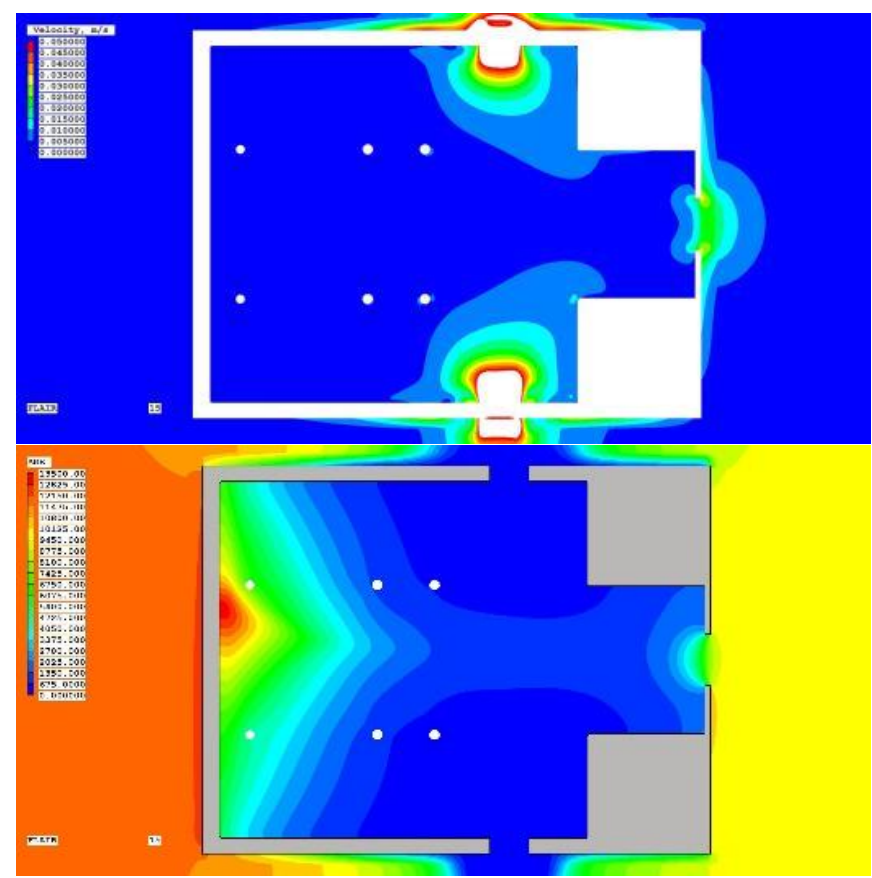

Figure 16. The wind speed and air age at the height of $1.5 \mathrm{~m}$ when the patio opening is $15 \mathrm{~m}^{2}$

\subsection{Plan 2 (adding more openings)}

The indoor ventilation directly hinges on the size and wind pressure of each opening. Hence, Plan 2 attempts to add several openings, which are of the same size with the existing ones, to improve indoor ventilation. Depending on the wind pressure distribution on building surface, the new openings were added on the exterior walls, which are under different wind pressures [12-15].

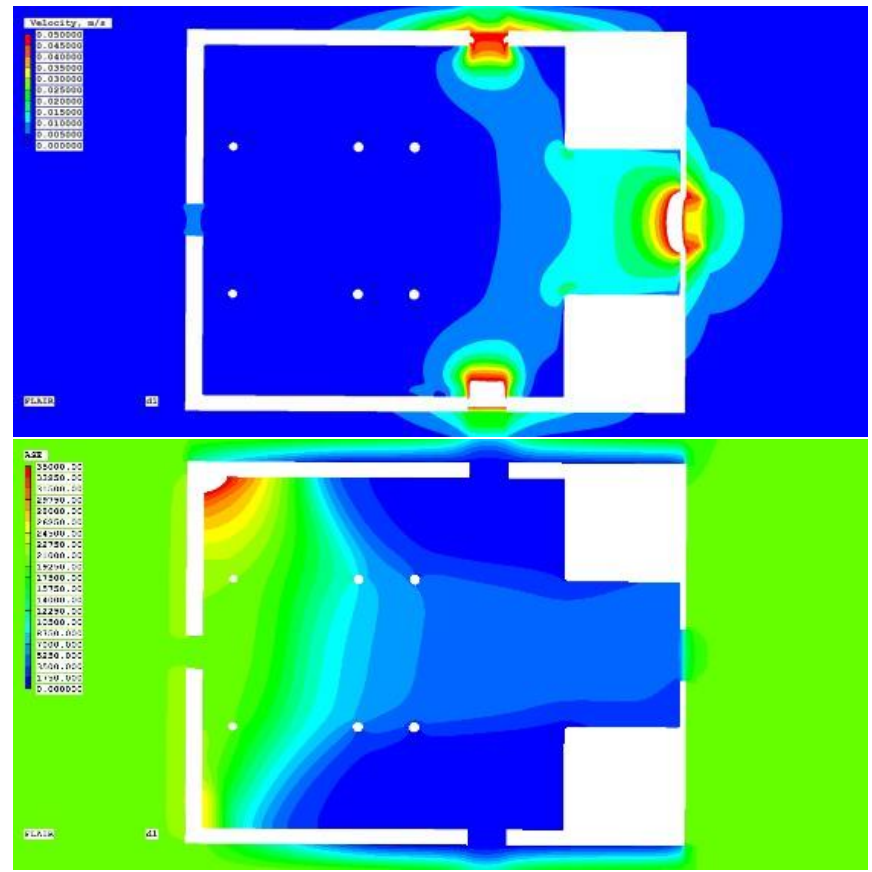

Figure 17. The wind speed and air age at the height of $1.5 \mathrm{~m}$ with a new opening on the southeast wall

According to the surface wind pressure in Figure 12, three new openings were added in turn to the target building, respectively on the southwest, northwest and southest exterior walls. All the openings were $1 \mathrm{~m} \times 2 \mathrm{~m}$ in size, with the lower edge at $1 \mathrm{~m}$ above the ground. The indoor wind environment simulated at these openings are displayed in Figures 17 19, and the wind pressure of each opening is listed in Table 2.

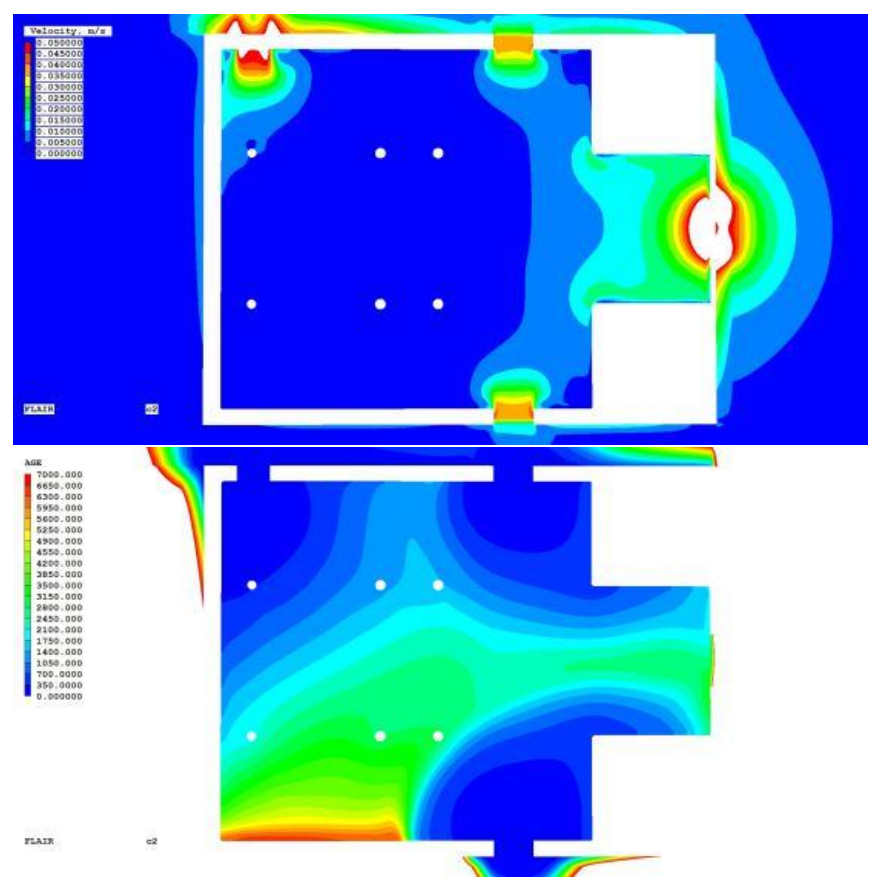

Figure 18. The wind speed and air age at the height of $1.5 \mathrm{~m}$ with a new opening on the southwest wall 


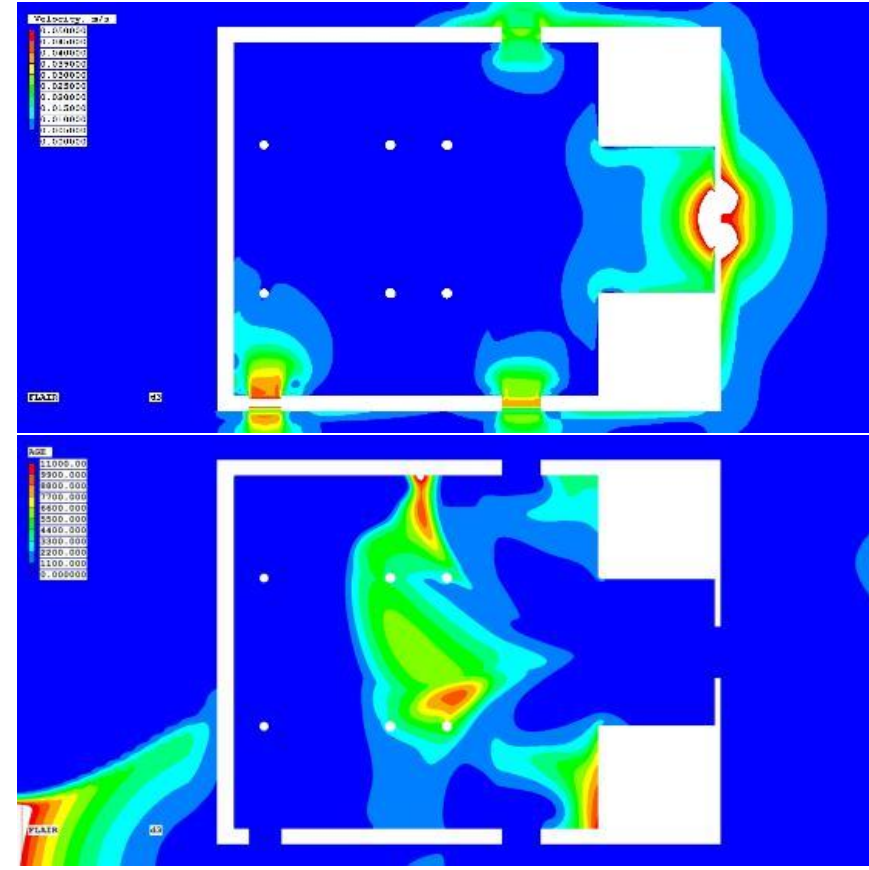

Figure 19. The wind speed and air age at the height of $1.5 \mathrm{~m}$ with a new opening on the northeast wall

In all three cases, the indoor wind speed always fell within $0 \sim 0.05 \mathrm{~m} / \mathrm{s}$; the second case had the largest indoor area with wind speed greater than $0.05 \mathrm{~m} / \mathrm{s}$ at the height of $1.5 \mathrm{~m}$, followed by the third case and the first case; the maximum air age indoor was respectively $35,000 \mathrm{~s}, 7,000 \mathrm{~s}$ and $11,000 \mathrm{~s}$ in the three cases. Therefore, the new opening on the southwest wall led to the most significant improvement to indoor ventilation, followed by that on the northeast wall, and then that on the southeast wall. Comparing the wind pressures of the three openings with the simulation results, it can be seen that the indoor ventilation improves with the increase of the absolute difference between the wind pressure of the new opening and that of the existing openings [16-17].

\subsection{Summary}

The simulation reveals that enlarging patio opening and adding new openings can both improve indoor ventilation of Xingfu Hall. The improvement effect of the former strategy is rather limited. Meanwhile, the indoor ventiation can be greatly improved by adding openings at places, where there is a large difference between the surface wind pressure at the new opening and the wind pressure of the existing openings.

\section{CONCLUSIONS}

In Huizhou architecture, the patio can improve the indoor wind environment, thanks to its chimney effect. The indoor ventilation is also greatly affected by the outdoor wind environment and the location of openings on the building.

For occupants in Wufu Club, the indoor ventilation could be improved by enlarging patio opening (wind outlet) and adding new openings (wind inlets). The ventilation effect improves with the growth in the size of openings, and with the absolute difference between the surface wind pressure at the new opening and the wind pressure of the existing openings.

These conclusions shed new light on the renovation and sustainable development of Huizhou architecture.

\section{ACKNOWLEDGMENT}

This work supported by the National Key Research and Development Program of China in the 13th five-year (No. 2017YFC0702503), Major project of natural science of the Education Department of Anhui province (KJ2016SD13), the program of supporting outstanding young talents in universities of Anhui Provincial Department of Education (No. gxyq2018029).

\section{REFERENCES}

[1] Shi, Q., Zhao, L. (2013). Research on energy saving design strategy of new traditional residence in Jinzhong, China. Advanced Materials Research, 689: 134-138. https://doi.org/10.4028/www.scientific.net/amr.689.134

[2] Xiong, K., Yang, Z. (2017). Energy-saving renovation of Bayu traditional residence: Taking Anju Town of Chongqing as the example. Procedia Engineering, 180: 687-696. https://doi.org/10.1016/j.proeng.2017.04.228

[3] Zhang, N., Zhang, S. (2014). Zhuhai traditional residence in the site selection and planning for natural ventilation. Applied Mechanics and Materials, 584-586, 859-862. https://doi.org/10.4028/www.scientific.net/AMM.584586.859

[4] Wang, L., Yang, Z., Yang, L. (2011). The research on environmental facility of traditional residence based on modern residence pattern takes the Dali courtyard traditional folk house as an example. 2011 International Conference on Electric Technology and Civil Engineering, ICETCE 2011-Proceedings, pp. 1751-1756. https://doi.org/10.1109/ICETCE.2011.5775406

[5] Tamene, Y., Serir, L. (2019). Thermal and economic study on building external walls for improving energy efficiency. International Journal of Heat and Technology, 37(1): 219-228. https://doi.org/10.18280/ijht.370127

[6] Mostafaei, A., Mirrzaei, M., Ghazvini, M., Ahmadi, M.H., Lorenzini, G. (2019). Investigation of energy saving in building by using phase-change materials (PCM). Mathematical Modelling of Engineering Problems, 6(1): 47-51. https://doi.org/10.18280/mmep.060106

[7] Li, Z., Shi, L. (2014). Research on suitability ecological updating technology system of traditional wooden residence. Advanced Materials Research, 945-949, 535538.

https://doi.org/10.4028/www.scientific.net/AMR.945949.535

[8] Huang, C., Zou, Z., Li, M., Wang, X., Li, W., Huang, W., Yang, J., Xiao, X. (2007). Measurements of indoor thermal environment and energy analysis in a large space building in typical seasons. Building and Environment, 42: $1869-1877$ https://doi.org/10.1016/j.buildenv.2006.02.016

[9] Wang, L., Hien, W.H. (2007). The impacts of ventilation strategies and facade on indoor thermal environment for naturally ventilated residential buildings in Singapore. Building and Environment, 42(12): 4006-4015. https://doi.org/10.1016/j.buildenv.2006.06.027

[10] Yoshino, H., Yoshino, Y., Zhang, Q., Mochida, A., Li, N., Li, Z., Miyasaka, H. (2006). Indoor thermal environment and energy saving for urban residential buildings in China. Energy and Buildings, 38(11): 1308- 
1319. https://doi.org/10.1016/j.enbuild.2006.04.006

[11] Rao, Y., Wang, D. (2014). Indoor ventilation and comfort evaluation of traditional folk houses under natural conditions in China. Advanced Materials Research, 955-959, 4087-4091 https://doi.org/10.4028/www.scientific.net/AMR.955959.4087

[12] Qian, W., Huang, Z., Zhao, L., Shi, T. (2013). Research on natural ventilation technology of traditional dwelling House in the Southern Area of Anhui Province. Lecture Notes in Electrical Engineering, 261: 429-437. https://doi.org/10.1007/978-3-642-39584-0_49

[13] Sun, L. (2012). The sun-shading technologies of the existing traditional dwellings in China. Advanced Materials Research, 689: 163-166. https://doi.org/10.4028/www.scientific.net/AMR.689.16 3

[14] Halim, I.A., Kayan, B.A., Mahmud, N.S. (2018). Green maintenance for heritage buildings: Low carbon laterite stones repair appraisal. Chemical Engineering Transactions, 63:

61-67. https://doi.org/10.3303/CET1863011

[15] Liu, J.W., Gao, S.Y. (2018). Study on the application of polymer thermal energy storage materials in building energy conservation system. Chemical Engineering Transactions, 66 337-343. https://doi.org/10.3303/CET1866057

[16] Wang, R.Z., Liu, P.D., Qian, Y.M., Zhan, J. (2018). On the integrated design of existing multi-storey residential building and integral solar water heater. Chemical Engineering Transactions, 66: 313-319. https://doi.org/10.3303/CET1866053

[17] Zhi, J. (2018). Application of thin polyurethane plastering thermal insulation system in building energy conservation. Chemical Engineering Transactions, 66: 349-355. https://doi.org/10.3303/CET1866059 